\title{
PENERAPAN MODEL MAKE A MATCH PADA PEMBELAJARAN FISIKA KELAS X SMA NEGERI 2 KOTA LUBUKLINGGAU
}

\author{
Endang Lovisia \\ STKIP-PGRI Lubuklinggau \\ lovisiae@gmail.com
}

Submit, 27-11-2017 Accepted,29-12-2017 Publish, 29-12-2017

\begin{abstract}
X student of SMA Negeri 2 Lubuklinggau after application of Make a Match model. The type of research is quantitative research with quasi-experimental research method, with one group pre-test and post-test design. The population in this study is all students of class X SMA Negeri 2 Lubuklinggau. Samples were taken randomly by drawing, so that the class X1 was obtained. Technique of collecting data using test technique. Based on the results of post-test data analysis obtained the average value of students at 79.11 with $5 \%$ level of disturbance obtained $t_{\text {count }}=2.98$ and $t_{\text {table }}=1.684$ for $t_{\text {hitung }}>t_{\text {table }}$, it can be concluded that the results of physics learning class X SMA 2 Lubuklinggau after applied Model Make a Macth is significantly declared complete.
\end{abstract}

Keyword: Physics, Learning result, Make a Match.

\begin{abstract}
Abstrak: tujuan penelitian ini adalah untuk mengetahui hasil belajar fisika siswa kelas X SMA Negeri 2 Lubuklinggau setelah penerapan model Make a Match. Jenis penelitian adalah penelitian kuantitatif dengan metode penelitian eksperimen semu, dengan desain one group pre-test dan post-test. Populasi dalam penelitian ini adalah seluruh siswa kelas X SMA Negeri 2 Lubuklinggau. Sampel diambil secara acak dengan cara pengundian, sehingga didapat kelas $X_{1}$. Teknik pengumpulan data menggunakan teknik tes. Berdasarkan hasil analisis data post-test didapatkan nilai rata-rata siswa sebesar 79,11 dengan taraf kesukaran 5\% didapat $t_{\text {hitung }}=2,98$ dan $t_{\text {tabel }}=1,684$ karena $t_{\text {hitung }}>t_{\text {tabel }}$, maka dapat disimpulkan bahwa hasil belajar fisika siswa kelas X SMA Negeri 2 Lubuklinggau setelah diterapkan Model Make a Macth secara signifikan dinyatakan tuntas.
\end{abstract}

Kata Kunci : Fisika, Hasil Belajar, Make a Match.

\section{PENDAHULUAN}

Dalam situasi masyarakat yang selalu berubah, idealnya pendidikan tidak hanya berorientasi pada masa lalu dan masa kini, tetapi sudah seharusnya merupakan proses yang mengantisipasi dan membicarakan masa depan. Pendidikan hendaknya melihat jauh ke depan dan memikirkan apa yang akan dihadapi peserta didik di masa yang akan datang (Trianto, 2007). Lembaga pendidikan yaitu sekolah, menjadi tolak ukur dalam memberi gambaran kepada dunia luar tentang sejauh mana keberhasilan yang telah dicapai oleh dunia pendidikan. Pelajaran Fisika merupakan pelajaran di sekolah yang dinilai memegang peranan penting untuk pola pikir siswa dalam membentuk seseorang menjadi manusia yang berkualitas. Perkembangan ilmu pengetahuan dan teknologi tidak terlepas dari peranan Fisika, tetapi banyak orang yang berpendapat bahwa Fisika sebagai pelajaran yang paling sulit. Oleh karena itu, guru Fisika 
dituntut untuk bervariasi dalam kegiatan pembelajaran.

Proses belajar mengajar dapat berjalan baik apabila seluruh komponen sistem pembelajaran yang mempengaruhinya saling mendukung. Kegiatan pembelajaran merupakan proses belajar mengajar yang dilakukan oleh guru dan siswa untuk mencapai tujuan pendidikan yang telah ditetapkan. Selama proses belajarmengajar terjadi interaksi antara guru dan siswa. Menurut (Siregar dan Nara, 2010) guru yang kurang berinteraksi kelas sehingga siswa menjadi pasif. Kelas masih terfokus pada guru sebagai sumber utama pengetahuan, dan pengetahuan merupakan perangkat fakta yang harus dihapal oleh siswa. Akibatnya, siswa sulit untuk berkembang secara mandiri proses berpikirnya dan cenderung menjadi malas.

Menurut guru Fisika Kelas X SMA Negeri 2 Lubuklinggau, Model yang selama ini digunakan di SMA Negeri 2 Lubuklinggau adalah pembelajaran konvensional. Menurut (Djamarah, 2011) metode pembelajaran konvensional adalah metode pembelajaran tradisional atau disebut juga dengan metode ceramah, karena sejak dulu metode ini telah dipergunakan sebagai alat komunikasi lisan antara guru dengan anak didik dalam proses belajar dan pembelajaran. Dalam pembelajaran metode konvensional ditandai dengan ceramah yang diiringi dengan penjelasan serta pembagian tugas dan latihan. Pembelajaran pada metode konvesional, peserta didik lebih banyak mendengarkan penjelasan guru di depan kelas dan melaksanakan tugas jika guru memberikan latihan soal-soal kepada peserta didik. dengan murid secara rutin akan menyebabkan proses belajar mengajar kurang lancar, dan menyebabkan anak didik merasa ada jarak dengan guru, sehingga segan untuk berpartisipasi aktif dalam kegiatan belajar-mengajar.

Dalam proses pembelajaran, guru harus bisa memilih dan menentukan model pembelajaran yang tepat agar siswa dapat belajar secara efektif. Model mengajar yang digunakan guru selama ini masih konvensional. Pada pembelajaran ini gurumendominasi

Agar dapat meningkatkan hasil belajar siswa, guru harus lebih kreatif dan inovatif dalam mengajar dengan mulai melakukan perubahan model pembelajaran yang mampu membuat suasana pembelajaran menjadi menarik dan menyenangkan bagi siswa dalam mempelajari Fisika sehingga terlihat peningkatan hasil belajar siswa. Salah satu alternatif yang dapat digunakan untuk mengatasi permasalahan di atas dengan menerapkan model pembelajaran Make a Match.

Model pembelajaran Make a Match merupakan salah satu pembelajaran kooperatif. Menurut Artzt \& Newman (dalam Trianto, 2010) menyatakan bahwa dalam belajar kooperatif siswa belajar bersama sebagai suatu tim dalam menyelesaikan tugas-tugas kelompok untuk mencapai tujuan bersama. Salah satu keunggulannya adalah siswa mencari pasangan sambil belajar mengenai suatu konsep atau topik dalam suasana yang menyenangkan. Model ini bisa digunakan dalam semua mata pelajaran dan untuk tingkatan usia anak didik.

Berdasarkan uraian di atas maka penulis tertarik untuk mengadakan penelitian dengan judul "Penerapan Model Make a Match Pada Pembelajaran Fisika Siswa Kelas X 
SMA Negeri 2 Lubuklinggau. Tujuan penelitian ini adalah untuk mengetahui ketuntasan hasil belajar fisika siswa kelas X SMA Negeri 2 Lubuklinggau setelah penerapan model Make a Match.

\section{LANDASAN TEORI \\ Tinjauan Tentang Belajar}

Dalam keseluruhan proses pendidikan di sekolah, kegiatan belajar merupakan kegiatan yang paling pokok. Ini berarti bahwa berhasil tidaknya pencapaian tujuan pendidikan banyak bergantung kepada bagaimana proses belajar yang dialami oleh siswa sebagai anak didik (Slameto, 2010).

Belajar merupakan tindakan dan perilaku siswa yang kompleks. Sebagai tindakan, maka belajar hanya dialami oleh siswa sendiri. Siswa adalah penentu terjadinya atau tidak terjadinya proses belajar. Proses belajar terjadi berkat siswa memperoleh sesuatu yang ada di lingkungan sekitar. Lingkungan yang dipelajari oleh siswa berupa keadaan alam, benda-benda, hewan, tumbuhan, manusia, atau hal-hal yang dijadikan bahan belajar (Dimyati dan Mudjiono, 2006).

Menurut Cronbach (dalam Suprijono, 2009) Learning is shown by a change in behavior as a result of experience. (Belajar adalah perubahan perilaku sebagai hasil dari pengalaman). Berdasarkan beberapa pendapat di atas maka dapat disimpulkan bahwa pengertian belajar adalah suatu proses yang dialami individu dalam interaksi dengan lingkungannya yang menghasilkan perubahan ke arah positif.

\section{Tinjauan Tentang Hasil Belajar Pengertian Hasil Belajar}

Didalam proses belajar mengajar, guru sebagai pengajar dan sekaligus pendidik memegang peranan dan tanggung jawab yang besar dalam rangka membantu meningkatkan keberhasilan siswa. Bukti bahwa seseorang telah belajar ialah terjadinya perubahan tingkah laku pada orang tersebut, misalnya dari tidak tahu menjadi tahu, dan dari tidak mengerti menjadi mengerti. Tingkah laku manusia terdiri dari sejumlah aspek. Hasil belajar akan tampak pada setiap perubahan pada aspek-aspek tersebut. Adapun aspek-aspek itu adalah: (1) pengetahuan, (2) pengertian, kebiasaan, (4) keterampilan, apresiasi, (6) emosional, (7) hubungan sosial, (8) jasmani, (9) etis atau budi pekerti, dan (10) sikap.

Menurut (Suprijono, 2009) hasil belajar adalah pola-pola perbuatan, nilai-nilai, pengertian-pengertian, sikap-sikap, apresiasi dan keterampilan. Menurut (Dimyati dan Mudjiono, 2006) Hasil belajar merupakan suatu puncak proses belajar. Berdasarkan beberapa pendapat di atas maka dapat disimpulkan bahwa pengertian hasil belajar adalah hasil yang diperoleh berupa perubahan yang menyeluruh dalam diri individu berkat interaksi yang terjadi antara individu dengan lingkungannya.

a. Faktor-faktor yang Mempengaruhi Hasil Belajar

Menurut (Slameto 2010), faktor-faktor yang mempengaruhi belajar siswa yaitu sebagai berikut:

1) Faktor-faktor internal

Faktor internal adalah faktor yang berada dari dalam diri siswa, yang termasuk dalam faktor internal adalah:

a) Faktor Jasmani, seperti kesehatan dan cacat tubuh.

b) Faktor psikologis, seperti intelegensi, perhatian, minat, bakat,motivasi, pematangan, dan kesiapan. 
c) Faktor kelelahan, yaitu kelelahan jasmani dan kelelahan rohani.

2) Faktor-faktor eksternal

Faktor eksternal adalah faktor yang berasal dari luar diri siswa, yang termasuk faktor eksternal adalah:

a) Faktor keluarga, misalnya cara orang tua mendidik, relasi antar anggota keluarga, suasana rumah, keadaan ekonomi keluarga, pengertian orang tua, latar belakang kebudayaan.

b) Faktor sekolah, misalanya metode mengajar, kurikulum, relasi guru dan siswa, relasi siswa dan siswa, disiplin sekolah, alat pelajaran, waktu sekolah, standar pelajaran di atas ukuran, keadaan gedung, metode belajar dan tugas rumah.

c) Faktor masyarakat, misalnya kegiatan siswa dalam masyarakat, media massa, teman bergaul, dan bentuk kehidupan masyarakat.

\section{Pengertian Pembelajaran}

Pembelajaran merupakan proses komunikasi dua arah, mengajar dilakukan oleh pihak guru sebagai pendidik, sedangkan belajar dilakukan oleh peserta didik atau murid. Menurut Dimyanti dan Mudjiono (dalam Sagala, 2010), pembelajaran adalah kegiatan guru secara terprogram dalam desain instruksional, untuk membuat siswa belajar secara aktif, yang menekankan pada penyediaan sumber belajar.

Sedangkan menurut (Suprijono, 2010), pembelajaran berdasarkan makna leksikal berarti proses, cara, perbuatan mempelajari. Jadi, pembelajaran adalah suatu proses belajar mengajar yang tidak hanya sekedar menyampaikan materi yang akan disampaikan akan tetapi juga dimaknai sebagai pengatur lingkungan supaya siswa belajar.

\section{Pengertian Model Pembelajaran}

Untuk mengatasi berbagai problematika dalam pelaksanaan pembelajaran, tentu diperlukan modelmodel pembelajaran yang dipandang mampu mengatasi kesulitan guru melaksanakan tugas mengajar dan kesulitan belajar peserta didik.

Joyce \& Weil (dalam Rusman, 2010) berpendapat bahwa model pembelajaran adalah suatu rencana atau pola yang dapat digunakan untuk membentuk kurikulum (rencana pembelajaran jangka panjang), merancang bahan-bahan pembelajaran, dan membimbing pembelajaran di kelas atau yang lain. Menurut Kardi, S. dan Nur (dalam Trianto, 2007) model pembelajaran mengacu pada pendekatan pembelajaran yang akan digunakan, termasuk di dalamnya tujuan-tujuan pengajaran, tahap-tahap kegiatan pembelajaran, lingkungan pembelajaran, dan pengelolaan kelas.

Model pembelajaran adalah kerangka konseptual yang melukiskan prosedur sistematik dalam mengorganisasikan pengalaman belajar untuk mencapai tujuan belajar (Trianto, 2007). Sedangkan menurut Suprijono (2009) model pembelajaran ialah pola yang digunakan sebagai pedoman dalam merencanakan pembelajaran di kelas maupun tutorial.

Berdasarkan beberapa pendapat di atas maka dapat disimpulkan bahwa model pembelajaran adalah pola yang digunakan sebagai pedoman dalam merencanakan pembelajaran di kelas oleh guru untuk mencapai tujuan belajar. 


\section{Model Pembelajaran Kooperatif}

Menurut Eggen dan Kauchak (dalam Trianto, 2007) pembelajaran kooperatif merupakan sebuah kelompok strategi pengajaran yang melibatkan siswa bekerja secara berkolaborasi untuk mencapai tujuan bersama. Slavin (dalam Isjoni, 2007:12) Cooperative Learning adalah suatu model pembelajaran dimana siswa belajar dan bekerja dalam kelompokkelompok kecil secara kolaboratif yang anggotanya 4-6 orang dengan struktur kelompok heterogen.

(Suprijono, 2009) pembelajaran kooperatif adalah konsep yang lebih luas meliputi semua jenis kerja kelompok termasuk bentuk-bentuk yang lebih dipimpin oleh guru atau diarahkan oleh guru. Menurut Johnson \& Johnson (dalam Isjoni, 2007) cooperative learning adalah mengelompokkan siswa di dalam kelas ke dalam suatu kelompok kecil agar siswa dapat bekerja sama dengan kemampuan maksimal yang mereka miliki dan mempelajari satu sama lain dalam kelompok tersebut.

Berdasarkan beberapa pendapat diatas maka dapat disimpulkan bahwa pengertian pembelajaran kooperatif/cooperative learning adalah proses belajar dengan menggunakan kelompok dalam menyelesaikan suatu permasalahan untuk mencapai tujuan bersama.

\section{Model Pembelajaran Kooperatif Tipe Make a Match}

a. Pengertian Model Pembelajaran Kooperatif Tipe Make a Match Menurut (Rusman, 2010) Make $a$ Match (membuat pasangan) merupakan salah satu jenis dari model pembelajaran kooperatif. Salah satu keunggulan model pembelajaran Make a Matcha dalah siswa mencari pasangan sambil belajar mengenai suatu konsep atau topik dalam suasana yang menyenangkan. Penerapan Make a Match, yaitu siswa disuruh mencari pasangan kartu yang merupakan jawaban/soal sebelum batas waktunya, siswa yang dapat mencocokkan kartunya diberi poin.

$\begin{array}{ccr}\begin{array}{c}\text { Dengan demikian } \\ \text { disimpulkan }\end{array} \text { bahwa } & \text { model }\end{array}$
pembelajaran Make a Match adalah salah satu variasi dari pembelajaran kooperatif dimana siswa mencari pasangan kartu yang sesuai dengan kartu yang dimiliki.

b. Langkah-langkah Model Pembelajaran Kooperatif Tipe Make a Match

Langkah-langkah pembelajaran dengan model Make a Match menurut (Suprijono, 2009) adalah sebagai berikut :

1) Guru menyiapkan kartu-kartu yang terdiri dari kartu-kartu berisi pertanyaan dan kartu lainnya berisi jawaban dari pertanyaan tersebut.

2) Guru membagi siswa menjadi 3 kelompok.

3) Kelompok pertama memegang kartu berisi pertanyaanpertanyaan, kelompok kedua memegang kartu yang berisi jawaban-jawaban, dan kelompok ketiga bertugas sebagai penilai.

4) Guru mengatur posisi duduk siswa berbentuk huruf U. kelompok pertama dan kedua berjajar saling berhadapan.

5) Guru membunyikan peluit sebagai tanda agar kelompok pertama maupun kelompok kedua saling bergerak mencari pasangan pertanyaan-jawaban yang cocok. 
6) Guru memberikan kesempatan siswa untuk berdiskusi.

7) Setelah selesai berdiskusi, maka pasangan yang telah terbentuk berdasarkan pertanyaan dan jawaban yang cocok menunjukkan kepada kelompok penilai.

8) Kelompok penilai memberikan penilaian terhadap pasangan dan membaca apakah pasangan pertanyaan-jawaban itu cocok.

9) Selanjutnya, kelompok pertama dan kelompok kedua bersatu menjadi kelompok penilai.

10) Kelompok penilai dibagi menjadi dua, sebagian anggota memegang kartu pertanyaan sebagian lainnya memegang kartu jawaban seperti langkah ketiga sampai dengan langkah kedelapan.

11) Guru dan siswa bersama-sama membahas hasil diskusi dan membuat kesimpulan terhadap materi pelajaran.

Sedangkan menurut (Suyatno, 2009) langkah-langkah dalam model pembelajaran Make a Match adalah sebagai berikut :

1) Guru menyiapkan beberapa kartu yang berisi beberapa konsep atau topik yang cocok untuk sesi review, sebaliknya satu bagian kartu soal dan bagian lainnya kartu jawaban.

2) Setiap siswa mendapat satu buah kartu.

3) Tiap siswa memikirkan jawaban/soal dari kartu yang dipegang.

4) Setiap siswa mencari pasangan yang mempunyai kartu yang cocok dengan kartunya (soal jawaban).
5) Setiap siswa yang dapat mencocokkan kartunya sebelum batas waktu diberi poin.

6) Setelah satu babak kartu dikocok lagi agar tiap siswa mendapat kartu yang berbeda dari sebelumnya.

7) Demikian seterusnya.

8) Kesimpulan/penutup.

Berdasarkan beberapa pendapat di atas maka dapat disimpulkan bahwa langkah-langkah pembelajaran dengan model Make a Match yang akan digunakan dalam penelitian ini adalah sebagai berikut :

1) Guru menyiapkan beberapa kartu yang terdiri dari kartu yang berisi pertanyaan dan jawaban.

2) Guru membagi siswa menjadi tiga kelompok yaitu kelompok pertama pemegang kartu pertanyaan, kelompok kedua pemegang kartu jawaban dan kelompok ketiga sebagai kelompok penilai.

3) Kelompok pemegang pertanyaan dan kelompok pemegang jawaban mendapatkan satu buah kartu.

4) Guru memberikan isyarat, maka kelompok pertama dan kelompok kedua saling bergerak untuk bertemu, mencari pasangan pertanyaan-jawaban yang cocok.

5) Guru memberikan kesempatan kepada mereka untuk berdiskusi.

6) Setelah selesai berdiskusi, maka pasangan yang telah terbentuk berdasarkan pertanyaan dan jawaban yang cocok menunjukkan kepada kelompok penilai.

7) Kelompok penilai memberikan penilaian terhadap pasangan dan membacakan apakah pertanyaanjawaban tersebut cocok atau tidak. 
8) Untuk mengetahui pertanyaan dan jawaban tersebut cocok atau tidak maka guru dan siswa membahasnya bersama-sama.

9) Pasangan yang dapat mencocokkan kartunya sebelum batas waktu yang ditentukan habis akan diberi poin.

10) Pada babak kedua, kelompok pertama dan kelompok kedua bersatu untuk menjadi kelompok penilai.

11) Kelompok penilai dibagi menjadi dua, yaitu kelompok pemegang kartu pertanyaan dan kelompok pemegang kartu jawaban seperti pada langkah kedua sampai dengan langkah kesembilan.

12) Guru dan siswa bersama-sama membuat kesimpulan terhadap materi pelajaran tersebut.

c. Kelebihan dan Kelemahan Model Pembelajaran Koopertaif Tipe Make a Match

Kelebihan model Make a Match adalah sebagai berikut:

1) Suasana kegembiraan akan tumbuh dalam proses pembelajaran.

2) Kerjasama antara siswa terwujud dengan dinamis.

3) Munculnya dinamika gotong royong yang merata diseluruh siswa.

Sedangkan kelemahan model Make a Match adalah jika kelas yang diteliti termasuk kelas gemuk (lebih dari 30 orang/kelas) berhati-hatilah, karena jika guru kurang bijaksana maka yang muncul adalah suasana seperti pasar dengan suasana yang tidak terkendali. Tentu saja kondisi ini akan mengganggu ketenangan belajar kelas di kiri kanannya.

\section{METODE PENELITIAN \\ Rancangan Penelitian}

Menurut (Arikunto, 2010), metode penelitian adalah cara yang digunakan oleh peneliti dalam mengumpulkan data penelitiannya. (Arikunto, 2010) juga mengemukakan bahwa "desain penelitian adalah rencana atau rancangan yang dibuat oleh peneliti, sebagai ancar-ancar kegiatan, yang akan dilaksanakan". Jenis penelitian yang digunakan dalam penelitian ini adalah quasi eksperimen atau eksperimen semu. Menurut (Arikunto, 2010) quasi eksperimen merupakan jenis eksperimen yang belum memenuhi persyaratan seperti cara eksperimen yang dapat dikatakan ilmiah mengikuti peraturan-peraturan tertentu. Design yang digunakan dalam penelitian ini adalah one group pre-test post-test design, menurut (Arikunto, 2010), desain eksperimen semu dapat dilihat pada tabel 1 .

Tabel 1. one group pre-test post-test design

\begin{tabular}{ccc}
\hline $\begin{array}{c}\text { Tes } \\
\text { awal }\end{array}$ & Perlakuan & $\begin{array}{c}\text { Tes } \\
\text { akhir }\end{array}$ \\
\hline $\mathbf{0}_{1}$ & $\mathrm{X}$ & $0_{2}$ \\
\hline
\end{tabular}

Variabel penelitian adalah suatu atribut atau sifat atau nilai dari orang, obyek atau kegiatan yang mempunyai variasi tertentu yang ditetapkan oleh peneliti untuk dipelajari dan kemudian ditarik kesimpulannya (Sugiyono, 2011). Dalam penelitian ini ada dua variabel yang berhubungan antara satu variabel dengan variabel yang lain, yaitu variabel bebas dan variabel terikat.

$\begin{array}{crr}\begin{array}{c}\text { Variabel } \\ \text { merupakan }\end{array} & \begin{array}{r}\text { bebas } \\ \text { variabel }\end{array} & \text { adalah } \\ \text { yang }\end{array}$
mempengaruhi atau yang menjadi sebab perubahannya atau timbulnya variabel terikat, sedangkan variabel terikat merupakan variabel yang dipengaruhi atau yang menjadi akibat, 
karena variabel bebas (Sugiyono, 2011). Adapun yang menjadi variabel bebas dalam penelitian ini adalah model Make a Match, sedangkan variabel terikatnya adalah hasil belajar fisika siswa kelas X SMA Negeri 2 Lubuklinggau.

\section{Populasi dan Sampel Populasi Penelitian}

"Populasi adalah keseluruhan subjek penelitian" (Arikunto:2010). Sedangkan menurut (Sugiyono, 2011) populasi adalah wilayah generalisasi yang terdiri atas: obyek/ subyek yang mempunyai kualitas dan karakteristik tertentu yang ditetapkan oleh peneliti untuk dipelajari dan kemudian ditarik kesimpulannya. Berdasarakan pendapat beberapa ahli dapat disimpulkan bahwa populasi adalah seluruh subjek penelitian yang mempunyai karakteristik tertentu untuk dipelajari dan kemudian ditarik kesimpulannya. Adapun yang menjadi populasi dalam penelitian ini adalah seluruh siswa kelas X SMA Negeri 2 Lubuklinggau yang terdiri dari 8 kelas, dengan rincian dapat dilihat tabel 2 .

Tabel 2 Populasi Penelitian

\begin{tabular}{ccccc}
\hline No & Kelas & $\begin{array}{c}\text { Laki- } \\
\text { Laki }\end{array}$ & $\begin{array}{c}\text { Perem- } \\
\text { puan }\end{array}$ & $\begin{array}{c}\text { Jum- } \\
\text { lah }\end{array}$ \\
\hline 1. & X.1 & 17 & 28 & 45 \\
2. & X.2 & 16 & 29 & 45 \\
3. & X.3 & 15 & 27 & 42 \\
4. & X.4 & 18 & 26 & 44 \\
5. & X.5 & 21 & 20 & 41 \\
6. & X.6 & 18 & 20 & 38 \\
7. & X.7 & 20 & 20 & 40 \\
8. & X.8 & 22 & 19 & 41 \\
\multicolumn{6}{c}{ Jumlah } & $\mathbf{1 4 7}$ & $\mathbf{1 8 9}$ & $\mathbf{3 3 6}$ \\
\hline \multicolumn{6}{l}{}
\end{tabular}

\section{Sampel Penelitian}

Menurut Sugiyono (2011:62) sampel adalah bagian dari jumlah dan karakteristik yang dimiliki oleh populasi. Dalam penelitian ini sampel yang diambil yaitu satu kelas yang diambil secara acak dengan teknik random sampling (pengundian). (Arikunto, 2010) menyatakan, random sampling digunakan apabila peneliti mengambil sampel dengan cara diundi terhadap semua populasi. Dari hasil pengundian terpilih kelas X.1 sebagai kelas eksperimen yang diberikan perlakuan pembelajaran model Make a Match.

\section{Teknik Pengumpulan Data}

Teknik pengumpulan data adalah cara memperoleh data atau disebut juga netode pengumpulan data. Teknik pengumpulan data yang digunakan dalam penelitian ini adalah teknik tes. Tes adalah serentetan pertanyaan atau latihan serta alat lain yang digunakan untuk mengukur keterampilan, pengetahuan inteligensi, kemampuan atau bakat yang dimiliki oleh individu atau kelompok (Arikunto, 2010). Tes dilakukan sebanyak dua kali yaitu sebelum dan sesudah perlakuan dengan model pembelajaran Make a Match untuk memperoleh data kuantitatif tentang hasil belajar siswa. Pre-test diberikan untuk melihat kemampuan awal siswa dan post-test diberikan untuk memperoleh data tentang hasil belajar siswa setelah diberi perlakuan model pembelajaran Make a Match. Tes yang diberikan berbentuk soal essay dengan jumlah lima soal, materi tes adalah arus listrik.

\section{Teknik Analisis Data}

Teknik analisis data dalam penelitian ini adalah teknik kuantitatif. Setelah data terkumpul dari hasil pengumpulan data, maka kegiatan selanjutnya adalah melakukan analisis data tersebut. Teknik analisis data yang digunakan dalam penelitian adalah menggunakan cara statistik. 


\section{Menentukan Rata-rata dan \\ Simpangan Baku}

Menentukan skor rata-rata dan simpangan baku pada tes awal dan tes akhir untuk mengetahui hasil belajar pada kelas eksperimen semu dengan rumus:

$$
\bar{x}=\frac{\sum f i \cdot x_{i}}{f_{1}}
$$

Keterangan:

$\bar{x}$ : Nilai rata-rata sampel

$f_{i}$ : Frekuensi

$X_{i}$ : Titik tengah nilai tes

$$
s=\sqrt{\frac{\sum f_{i}\left(x_{i-} \bar{x}\right)^{2}}{n-1}}
$$

Keterangan:

$s$ : Simpangan baku

$\bar{x}$ : Nilai rata-rata sampel

$x_{i}$ : Titik tengah nilai $\mathrm{X}$

$n$ : Jumlah sampel keseluruhan

\section{Uji Normalitas}

Uji normalitas menggunakan rumus chi kuadrat yang bertujuan untuk menguji kesesuaian data dalam sebaran distribusi normal.

$$
\chi^{2}=\sum \frac{\left(f_{0}-f_{e}\right)^{2}}{f_{e}}
$$

Keterangan:

$\chi^{2}=$ harga Chi kuadrat yang dicari

$f_{0}=$ Frekuensi hasil observasi

$f_{e}=$ Frekuensi yang diharapkan

Selanjutnya, $\quad \chi_{\text {hitung }}^{2}$ dibandingkan dengan $\chi_{\text {tabel }}^{2}$ dengan derajat kebebasan $(d k)=n-1$. Dimana $n$ adalah banyaknya kelas interval data dengan signifikan 5\%. Jika $\chi_{\text {hitung }}^{2}<\chi_{\text {tabel }}^{2}$, maka distribusi data dinyatakan normal. Jika $\chi_{\text {hitung }}^{2} \geq$ $\chi_{\text {tabel }}^{2}$, maka dapat dinyatakan bahwa data tidak berdistribusi normal (Sugiyono, 2011).

\section{Uji Hipotesis}

Jika simpangan baku populasi tidak diketahui dan data berdistribusi normal, maka digunakan uji-t dengan rumus:

$$
t=\frac{\bar{x}-\mu_{0}}{\frac{s}{\sqrt{n}}}
$$

Keterangan:

$t=$ Nilai $\mathrm{t}$ yang dihitung, selanjutnya

disebut t hitung

$\bar{x}=$ Rata-rata $x_{i}$

$\mu_{0}=$ Nilai yang dihipotesiskan

$s=$ Simpangan baku

$n=$ Jumlah anggota sampel

Dimana :

$H_{a}$ : Rata-rata hasil belajar siswa kelas X SMA N 2 Lubuklinggau setelah penerapan model pembelajaran Make a Match lebih besar atau sama dengan $75(\mu \geq$ 75).

$H_{0}$ : Rata-rata hasil belajar siswa kelas $X$ SMA $\mathrm{N} 2$ Lubuklinggau setelah penerapan model pembelajaran Make a Match kurang dari $75(\mu<75)$.

\section{Pertanggung Jawaban Penelitian Uji Validitas}

Menurut (Arikunto, 2010) validitas adalah suatu ukuran yang menunjukkan tingkat-tingkat kevalidan atau kesahihan sesuatu instrumen.

Menurut (Suherman dan Sukjaya, 1990), interprestasi yang lebih rinci mengenai nilai $r_{x y}$ tersebut dibagi dalam kategori seperti tabel 3 berikut ini.

Tabel 3. Kategori Uji Validitas Butir Soal

\begin{tabular}{ll}
\hline \multicolumn{1}{c}{$\begin{array}{c}\text { Nilai Koefisien } \\
\text { Korelasi }\end{array}$} & \multicolumn{1}{c}{ Keterangan } \\
\hline$r_{x y} \leq 0,00$ & Tidak valid \\
$0,00<r_{x y} \leq 0,20$ & Validitas sangat \\
$0,20<r_{x y} \leq 0,40$ & rendah \\
\hline
\end{tabular}




\begin{tabular}{ll}
$0,40<r_{x y} \leq 0,60$ & Validitas rendah \\
$0,60<r_{x y} \leq 0,80$ & Validitas sedang \\
$0,80<r_{x y} \leq 1,00$ & Validitas tinggi \\
& Validitas sangat tinggi \\
\hline
\end{tabular}

Untuk menentukan keberartian dari koefisien validitas digunakan uji-t dengan rumus sebagai berikut:

$$
t=r_{x y} \sqrt{\frac{n-2}{1-r_{x y}^{2}}}
$$

Keterangan:

$n=$ banyak data,

$r_{x y}=$ korelasi product momment,

$t=$ distribusi student.

Harga thitung diperoleh untuk taraf kesalahan 5\% uji satu pihak dengan $\mathrm{dk}=\mathrm{n}-1$. Jika thitung $>$ ttabel, maka $H_{a}$ diterima dan $H_{0}$ ditolak dengan kata lain terdapat hubungan signifikan atau butir soal dikatakan valid.

\section{Uji Realibilitas}

Instrumen yang reliabel berarti instrumen yang bila digunakan beberapa kali untuk mengukur obyek yang sama, akan menghasilkan data yang sama (Sugiyono, 2011).

Rumus yang digunakan untuk mencari nilai koefisien bentuk uraian adalah dengan rumus Alpha $\left(r_{11}\right)$, yaitu sebagai berikut;

$$
r_{11}=\left(\frac{k}{k-1}\right)\left(1-\frac{\sum \sigma_{b}^{2}}{\sigma_{t}^{2}}\right)
$$

Keterangan :

$r_{11}$ : Reliabilitas instrumen

$\mathrm{K}$ : Banyaknya butir pertanyaan atau banyaknya soal

$\sum \sigma_{b}^{2}:$ Jumlah varians butir

$\sigma_{t}^{2} \quad$ : Varians total

Tabel 4. Kategori Uji Reliabilitas

\begin{tabular}{lc}
\hline $\begin{array}{c}\text { Nilai Reliabilitas } \\
\text { Instrumen }\end{array}$ & Keterangan \\
\hline$r_{11} \leq 0,20$ & Reliabilitas sangat \\
\hline
\end{tabular}

\begin{tabular}{ll}
\hline $0,20<r_{11} \leq 0,40$ & rendah \\
$0,40<r_{11} \leq 0,60$ & Reliabilitas rendah \\
$0,60<r_{11} \leq 0,80$ & Reliabilitas sedang \\
$0,80<r_{11} \leq 1,00$ & Reliabilitas tinggi \\
& Reliabilitas sangat tinggi \\
\hline
\end{tabular}

\section{Daya Pembeda}

Daya pembeda sebuah butir soal adalah kemampuan butir soal itu untuk membedakan antara testi (siswa) yang pandai atau berkemampuan tinggi dengan siswa yang bodoh (Suherman dan Sukjaya, 1990). Untuk menentukan daya pembeda digunakan rumus :

$$
D P=\frac{J B_{A-} J B_{B}}{J S_{A}}
$$

Keterangan :

$D P \quad$ : Indeks daya pembeda

$J B_{A}$ : Jumlah skor kelompok atas

$J B_{B} \quad$ : Jumlah skor kelompok bawah

$J S_{A} \quad$ : Jumlah skor ideal kelompok atas

Menurut Suherman dan Sukjaya (1990), klasifikasi interprestasi untuk daya pembeda dapat dilihat seperti tabel 5 .

Tabel 5. Klasifikasi Daya Pembeda Butir Soal

\begin{tabular}{cc}
\hline $\begin{array}{c}\text { Indeks Daya } \\
\text { Pembeda }\end{array}$ & Keterangan \\
\hline$D P \leq 0,00$ & Sangat jelek \\
$0,00<D P \leq 0,20$ & Jelek \\
$0,20<D P \leq 0,40$ & Cukup \\
$0,40<D P \leq 0,70$ & Baik \\
$0,70<D P \leq 1,00$ & Sangat baik \\
\hline
\end{tabular}

\section{Tingkat Kesukaran}

Derajat kesukaran suatu butir soal dinyatakan dengan bilangan yang disebut Indeks Kesukaran (Difficulty Index). Bilangan tersebut adalah bilangan real pada interval 0,00 sampai dengan 1,00. Soal dengan indeks kesukaran mendekati 0,00 berarti butir soal tersebut terlalu sukar, sebaliknya soal dengan indeks kesukaran 1,00 berarti soal tersebut terlalu mudah (Suherman dan Sukjaya, 1990). Soal yang tingkat kesukarannya sedang, sebab bila tingkat kesukaran soal itu 
sedang maka dapat memberikan informasi mengenai perbedaan individual yang paling besar. Rumus untuk menghitung indeks kesukaran butir soal yaitu:

$$
I K=\frac{J B_{A}+J B_{B}}{J S_{A}+J S_{B}}
$$

Keterangan :

IK : Indeks Kesukaran

$J B_{A} \quad$ : Jumlah skor kelompok atas

$J B_{B} \quad$ : Jumlah skor kelompok bawah

$J S_{A} \quad$ : Jumlah skor ideal kelompok atas

$J S_{B} \quad$ : Jumlah skor ideal kelompok bawah

Tabel 6. Klasifikasi Indeks Kesukaran Butir Soal

\begin{tabular}{cc}
\hline Indeks Kesukaran & Keterangan \\
\hline$I K=0,00$ & Soal terlalu sukar \\
$0,00<I K \leq 0,30$ & Soal sukar \\
$0,30<I K \leq 0,70$ & Soal sedang \\
$0,70<I K<1,00$ & Soal mudah \\
$I K=1,00$ & Soal terlalu mudah \\
\hline
\end{tabular}

Berdasarkan analisis tes hasil uji coba tes instrumen, maka soal yang akan digunakan untuk tes adalah soal yang memenuhi syarat validitas, daya pembeda, dan tingkat kesukaran yang baik. Dari 7 soal yang diujikan, ada 5 soal yang dipakai dan 2 soal yang tidak dipakai sebagai instrumen dalam penelitian, soal yang dipakai pada penelitian ini adalah soal nomor $1,2,3,5$, dan 7. Sedangkan soal nomor 4 dan nomor 6 tidak dipakai sebagai butir soal instrumen penelitian, karena memiliki validitas dan daya pembeda yang rendah.

\section{HASIL DAN PEMBAHASAN Hasil Penelitian}

Penelitian ini dilaksanakan di kelas X SMA Negeri 2 Lubuklinggau Tahun, dimulai dari tanggal 20 April sampai 20 Mei 2015 Jumlah seluruh siswa kelas $X$ yaitu sebanyak 336 siswa dari 8 kelas yang ada. Sebelum memulai pembelajaran peneliti terlebih dahulu menginformasikan pelaksanaan model pembelajaran Make a Match, dan materi yang akan diajarkan yaitu arus listrik. Jumlah pertemuan tatap muka yang dilakukan adalah empat kali pertemuan dengan rincian satu kali pemberian pre-test, dua kali proses pembelajaran dengan model pembelajaran Make a Match dan satu kali pemberian post-test.

Pemberian pre-test digunakan untuk mengetahui kemampuan awal siswa sebelum mengikuti pembelajaran dengan menggunakan model pembelajaran Make a Match. Setelah kemampuan awal siswa diketahui, dilakukan kegiatan pembelajaran dengan menggunakan model pembelajaran Make a Match. Kegiatan pembelajaran dilaksanakan sebanyak 2 kali pertemuan. Pada akhir penelitian dilakukan post-test untuk mengetahui hasil belajar siswa.

\section{Data Hasil Kemampuan Awal Siswa (pre-test).}

Pemberian tes awal digunakan untuk mengetahui kemampuan awal siswa pada materi kuat arus. Kemampuan awal siswa adalah kemampuan yang dimiliki siswa sebelum mengikuti pembelajaran yang diberikan. Kemampuan awal tersebut menggambarkan kesiapan siswa dalam menerima pembelajaran yang akan disampaikan oleh guru.

Pemberian tes awal dilakukan pada tanggal 27 April 2015 yang diikuti 45 siswa. Berdasarkan hasil perhitungan diketahui bahwa nilai ratarata yang diperoleh siswa sebesar 14,56 dengan ketuntasan siswa sebesar $0 \%$. Jadi dapat disimpulkan bahwa secara 
deskriptif kemampuan awal siswa sebelum penerapan model pembelajaran Make a Match termasuk kategori belum tuntas.

\section{Data Kemampuan Akhir Siswa (post- test).}

Setelah kemampuan awal siswa diketahui, dilanjutkan kegiatan pembelajaran dengan model pembelajaran Make a Match. Kegiatan pembelajaran dilaksanakan sebanyak dua kali pertemuan. Pada akhir penelitian dilakukan tes akhir untuk mengetahui kemampuan akhir siswa. Kemampuan akhir siswa adalah kemampuan siswa dalam penguasaan materi muatan arus listrik yang merupakan hasil belajar siswa setelah proses pembelajaran.

Berdasarkan hasil perhitungan rekapitulasi data tes akhir dapat diketahui bahwa rata-rata $(\bar{x})$ nilai secara keseluruhan sebesar 79,11 Jadi secara deskriptif dapat dikatakan bahwa kemampuan akhir siswa setelah penerapan model pembelajaran Make a Match termasuk dalam kategori tuntas.

Dari hasil analisis diperoleh bahwa rata-rata nilai tes awal adalah 14,56 dan untuk rata-rata nilai tes akhir adalah 79,11. Ini dapat dilihat bahwa terjadi peningkatan rata-rata nilai dari pre-test ke post-test sebesar 64,55. Sedangkan persentase jumlah siswa yang tuntas pada pre-test sebesar $0 \%$ dan pada post-test sebesar $73 \%$. Untuk ketuntasan belajar mengalami peningkatan sebesar $73 \%$.

\section{Analisis Interferensial Data Penelitian}

Analisis inferensial dilakukan untuk menguji hipotesis penelitian yang berbunyi "Hasil belajar fisika siswa kelas X SMA Negeri 2 Lubuklinggau setelah model pembelajaran Make a
Match secara signifikan sudah tuntas". Pada tahap ini analisis yang dilakukan adalah sebagai berikut:

\section{Uji Normalitas}

Uji normalitas bertujuan untuk mengetahui apakah data hasil tes siswa berdistribusi normal atau tidak. Untuk mengetahui kenormalan data, digunakan uji normalitas data dengan uji kecocokan $\chi^{2} \quad$ (chi-kuadrat). Berdasarkan ketentuan perhitungan statistik mengenai uji normalitas data dengan taraf kepercayaan $\alpha=0,05$, jika $\chi^{2}{ }_{\text {hitung }}<\chi^{2}{ }_{\text {tabel }}$ maka data berdistribusi normal. Dari Hasil perhitungan uji normalitas data post-test nilai $\chi^{2}$ hitung data post-test 7,9740 lebih kecil daripada nilai $\chi^{2}$ tabel 12,59 . Berdasarkan ketentuan pengujian normalitas dengan menggunakan uji kecocokan $\chi^{2}$ (chi-kuadrat) dapat disimpulkan bahwa data post-test berdistribusi normal. Pada taraf kepercayaan $\alpha=0,05$ dengan derajat kebebasan $(\mathrm{dk})=6$.

\section{Uji Hipotesis}

Hasil uji hipotesis untuk data post-test yang menggunakan uji-t mengenai kemampuan akhir (post-test) siswa menunjukkan bahwa $t_{\text {hitung }}$ $(2,98)>t_{\text {tabel }}(1,684)$ maka $\mathrm{H}_{\mathrm{O}}$ ditolak dan $\mathrm{H}_{\mathrm{a}}$ diterima. Dengan demikian hipotesis yang diajukan dalam penelitian ini dapat diterima kebenarannya, sehingga dapat disimpulkan bahwa "Hasil Belajar Fisika Siswa Kelas X SMA Negeri 2 Lubuklinggau Setelah Penerapan Model Pembelajaran Make a Match Secara Signifikan Tuntas". 


\section{Pembahasan}

Berdasarkan pada rumusan masalah yang dikemukakan dalam penelitian ini yaitu apakah hasil belajar fisika siswa kelas X SMA Negeri 2 Lubuklinggau setelah penerapan model pembelajaran Make a Match secara signifikan tuntas.

Setelah dilakukan perbandingan hasil tes awal dan tes akhir maka dapat diketahui bahwa terdapat peningkatan hasil belajar. Pada tes awal nilai ratarata siswa $(\bar{x})$ sebesar 14,56 dan setelah penerapan model pembelajaran Make a Match rata-rata hasil belajar siswa $(\bar{x})$ meningkat menjadi 79,11. Peningkatan yang terjadi sebesar 64,55. Jika dibandingkan dengan data tes awal, terdapat pula peningkatan jumlah siswa yang tuntas. Jika pada tes awal ketuntasan siswa $0 \%$ setelah penerapan siswa yang tuntas mencapai $73 \%$. Jadi terdapat peningkatan persentase jumlah siswa yang tuntas belajar sebesar $73 \%$.

Berdasarkan hasil analisis pengujian hipotesis diperoleh $t_{\text {hitung }}>t_{\text {tabel }}$ dengan demikian hipotesis yang diajukan dapat diterima kebenarannya, artinya hasil belajar siswa setelah penerapan model pembelajaran Make a Match secara signifikan tuntas.

Hasil penelitian ini sesuai dengan hasil penelitian yang dilakukan oleh Imron pada tahun 2012 yang berjudul "Penerapan Model Pembelajaran Kooperatif Tipe Make a Match Dalam Pembelajaran Fisika Siswa Kelas VII SMP Negeri Muara Beliti", rata-rata hasil belajar siswa sebesar 72,26 dan persentasi jumlah siswa yang tuntas $85 \%$ atau 29 siswa yang tuntas dan $15 \%$ atau 5 siswa yang tidak tuntas. Penelitian tersebut menyimpulkan bahwa hasil belajar fisika siswa setelah diterapkannya model pembelajaran kooperatif tipe
Make a Match di kelas VII SMP Negeri Muara Beliti signifikan tuntas.

Hasil penelitian ini didukung oleh temuan peneliti di lapangan selama proses belajar mengajar menggunakan model pembelajaran Make a Match, siswa terlihat lebih aktif, siswa cenderung siap mengikuti kegiatan pembelajaran dengan mempelajari terlebih dahulu materi yang akan dibahas di kelas. Dengan model pembelajaran Make a Match ini kecenderungan guru menjelaskan materi hanya dengan ceramah dapat dikurangi, sehingga siswa lebih bisa mengembangkan pengetahuannya sendiri sedangkan guru lebih banyak berfungsi sebagai fasilitator daripada mengajar.

Dalam proses belajar mengajar fisika menggunakan model pembelajaran Make a Match memungkinkan siswa dapat bekerja sama dengan temannya di mana siswa saling bekerja sama dalam mempelajari materi yang dihadapi. Dalam pembelajaran ini siswa dilatih untuk bekerja sama dengan baik kepada teman sekelas apa yang telah mereka kerjakan. Dari sini siswa memperoleh informasi maupun pengetahuan serta pemahaman yang berasal dari sesama teman dan guru. Perbedaan hasil belajar yang muncul juga disebabkan karena siswa yang diberi pembelajaran menggunakan model pembelajaran Make a Match mempunyai pengalaman dalam berkeja sama penukaran soal dan jawaban kepada teman.

Model pembelajaran Make a Matchdalam penelitian ini dilakukan secara berkelompok dengan berpasangan, siswa dibagi dalam kelompok kecil dengan jumlah 2 orang berpasangan dengan teman sebangkunya. Kemudian peneliti menjelaskan materi tentang arus listrik. 
Dalam kegiatan diskusi yaitu mengamati atau mencari jawaban, sehingga siswa dapat memahami serta menemukan konsep tentang arus listrik.

Proses pembelajaran pada pertemuan kedua dilakukan pada tanggal 11 April 2015 dengan materi hukum ohm yaitu membahas tentang hambatan rangkaian. Proses pembelajaran pada pertemuan kedua siswa sudah mulai memahami model pembelajaran, sehingga mereka langsung menyelidiki dan menemukan jawaban dari permasalahan yang diberikan peneliti dalam lembar kerja siswa, walaupun sebagian dari mereka mengalami kesulitan mungkin karena minimnya pengetahuan konsep fisika atau lupa pelajaran yang sudah dipelajari. Setelah melakukan kegiatan pengisisan soal dan jawaban setiap kelompok dipertemukan dan diberi kesempatan berdiskusi setelah berdiskusi siswa diharapkan mempresentasikan jawabannya didepan kelas.

Semua kelompok telah mencapai hasil yang baik karena pemahaman materi masih melekat, sehingga peran peneliti hanya mengecek dan mengawasi. Setelah melakukan kegiatan diskusi setiap kelompok diharapkan mempresentasikan didepan kelas, kemudian membuat kesimpulan.

Hambatan yang ditemukan peneliti pada waktu pembelajaran menggunakan model pembelajaran

Make a Match adalah sebagai berikut:

a. Peneliti masih mengalami kesulitan untuk menciptakan suasana kelas yang nyaman dan menyenangkan.

b. Kurang waktu efektif siswa didalam kelas.

c. Kebiasaan yang menerima dari guru menyebabkan siswa mengalami kesulitan dalam menghubungkan materi dengan lingkungan.

Untuk mengatasi hambatan yang ditemui selama kegiatan pembelajaran tersebut, maka peneliti melakukan langkah-langkah sebagai berikut:

a. Menata ruang kelas untuk memperkecil terjadinya keributan di dalam kelas seperti membuat bentuk U.

b. Peneliti lebih ekstra memperhatikan siswa yang kurang aktif, dan salah satu solusinya guru dapat menggunakan model pembelajaran Make a Match yang dapat merespon siswa belajar dengan melibatkan kerja sama yang baik.

c. Peneliti memperhatikan siswa saat belajar dan membantu siswa yang mengalami kesulitan dalam proses pembelajaran.

Hasil penelitian ini menunjukkan bahwadengan menggunakan model pembelajaran Makea Match hasil belajar fisika siswa SMA Negeri 2 Lubuklinggau secara signifikan tuntas. Walaupun masih ada 12 orang siswa $(27 \%)$ yang belum mencapai Kriteria Ketuntasan Minimal (KKM), namun hal tersebut sudah mengalami peningkatan.Berdasarkan analisis statistik terbukti bahwa pembelajaran fisika dengan menggunakan model pembelajaran Makea Match dapat mencapai tingkat ketuntasan hasil belajar siswa.

\section{SIMPULAN}

Berdasarkan hasil penelitian nilai rata-rata pre-test adalah 14,56 sedangkan nilai rata-rata post-test adalah 79,11 . Nilai rata-rata yang dihipotesiskan adalah 75. Presentasi ketuntasan siswa yang tuntas sebesar $73 \%$ dan siswa yang tidak tuntas $27 \%$. 
Nilai rata-rata post-test $79,11>75$ maka $\mathrm{H}_{\mathrm{a}}$ diterima. Dan $\mathrm{H}_{\mathrm{o}}$ ditolak. Kemudian hasil perhitungan uji-t pada post-test diperoleh thitung $t_{\text {hitung }}(2,98)>$ $\mathrm{t}_{\text {tabel }}(1,684)$ maka $\mathrm{H}_{\mathrm{O}}$ ditolak dan $\mathrm{H}_{\mathrm{a}}$ diterima, dengan demikian hipotesis yang diajukan dalam penelitian ini dapat diterima kebenarannya. pembahasan dapat disimpulkan bahwa "Hasil belajar Fisika siswa kelas $\mathrm{X}$ SMA Negeri 2 Lubuklinggau setelah penerapan model Make a Match secara signifikan tuntas".

\section{DAFTAR PUSTAKA}

Arikunto, Suharsimi. (2010). Prosedur Penelitian Suatu Pendekatan Praktik. Jakarta: Rineka Cipta

Dimyati dan Mudjiono. (2006). Belajar dan Pembelajaran. Jakarta: Rineka Cipta

Djamarah, Syaiful Bahri. (2011). Psikologi Belajar. Jakarta: Rineka Cipta

Isjoni. (2007). Cooperative Learning. Pekanbaru : Alfabeta

Rusman. (2010). Model-model Pembelajaran Mengembangkan Profesionalisme Guru. Bandung : PT RajaGrafindo Persada

Sagala, Syaiful. (2010). Konsep dan Makna Pembelajaran. Bandung: Alfabeta

Siregar dan Nara. (2010). Teori Belajar dan Pembelajaran. Jakarta: GhaliaIndonesia

Slameto. (2010). BelajarDan Faktorfaktor Yang Mempengaruhinya. Jakarta: Rineka Cipta

Sugiyono. (2011). Statistika untuk Penelitian. Bandung: Alfabeta

Suherman dan Sukjaya. 1990. Petunjuk Praktis untuk Melaksanakan Evaluasi Pendidikan Matematika. Bandung : Wijayakusumah

Suprijono, Agus. (2009). Cooperatif Learning : Teori dan Aplikasi PAIKEM.Yogyakarta: Pustaka Belajar

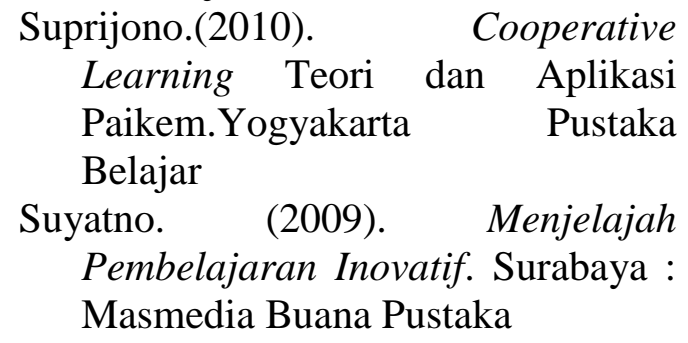


Trianto. (2007). Model-model Pembelajaran Inovatif Berorientasi Konstruktivistik. Surabaya: Prestasi Pustaka Publisher

Trianto. (2007). Model Pembelajaran Terpadu Dalam Teori Dan Praktek. Surabaya: Prestasi Pustaka

Trianto. (2010). Mendesain Model Pembelajaran Inovatif-Progresif. Jakarta : Prenada Media Group 